Ann. Génét. Sél. anim., I980, 12 (4), 313-320.

\title{
The relative length of Pig chromosomes, and a suggestion for a karyotype system
}

\author{
K. M. HANSEN \\ Institute of Medical Anatomy, Department B, University of Copenhagen \\ The Panum Institute, Blegdamsvej 3 \\ DK-220o Copenhagen $N$, Denmark
}

\section{Summary}

A revised study of the relative length of $p$ and $q$ of the different pairs of chromosomes from $\mathrm{I} 5$ cells of domestic pig (Sus scrofa domestica) is presented. The relative length of the $\mathrm{X}$ chromosome is $5 \mathrm{p}$. roo of the haploid female chromosome complement. Different karyotype systems, including the Reading Conference system for pig chromosomes, are discussed. A combination of the bi- and one-armed system, with the system by LEVAN et al. (1964) is recommended as an international karyotype system for pig chromosomes.

\section{Introduction}

Before the chromosome banding methods were introduced in the beginning of the seventies, the chromosomes were identified by the morphology and the relative length. The morphology was especially related to the subdivision bi- or one-armed chromosomes, and to the position of the centromere.

For several reasons, e.g. classification of chromosomes according to the system by LEVAN et al. (I964), which was decided to be used at the Reading Conference (1976), it is still necessary to know the relative length of the individual pairs of chromosomes as well as the length of $p$ and $q$.

The first measurements of the relative length of preidentified chromosomes of the domestic pig were published by HANSEN (I976a, I977). The measurements were based on ro cells. Recently LIN et al. (I980) have described the relative length of the pig chromosomes based on measurements of 13 cells. Because some difficulties have existed as regards the banding pattern of the $\mathrm{X}$ chromosome in different metaphase stages, HANSEN (I980), a revised study of the relative length of the chromosomes of the domestic pig is presented in this paper.

Based on the chromosome length and the arm ratio, the pig chromosomes 
are numbered according to the Reading karyotype system, and according to the two most logical systems, $I$ : the bi- and one-armed system, as approximately used by HANSEN-MEIANDER et al. (I974), and $2:$ the exact system by LEVAN et al. (I964).

\section{Materials and methods}

Blood cultures from pigs of different strains of Danish Landrace were prepared according to the method previously described by HANSEN (I972). The cells were stained by Quinacrine mustard dissolved in distilled water, $1.0 \mathrm{mg} / \mathrm{ml}$, mounted in McIlvain's buffer, $\mathrm{pH} 7.0$, and microphotographs were taken on an Ilford Pan-F film, I8 DIN. After fluorescence microscopy, the slides were rinsed in ethanol, 99, 70, and 30 p. I00, and restained by Giemsa solution, I.5 p. Ioo, for ro minutes. Mounted in DePeX, the cells were relocated and photographed on a Copex Pan film, Agfa-Gevaert, 9 DIN. Prints were made on a Rapidoprint LD-3 machine, using FP-I paper, contrast TP-6, H-4, and $\mathrm{H}-3$. Fifteen totally identified cells were used for measuring, and $p$ and $q$ were measured manually. The chromosomes were classified into groups according to the system by LEVAN et al. (1964), and termed $\mathrm{m}, \mathrm{sm}$, st, and $\mathrm{t}$, but arranged in karyotype according to the Reading Conference (I976), which use the illogical order sm, st, $\mathrm{m}$, and $\mathrm{t}$. Pair No. 5 in the preliminary Reading system has been changed to the right position in the metacentric group, as decided at the Conference, if further measurements confirm the results by HANSEN (I976a). Within the different groups and subgroups the chromosomes are arranged according to decreasing length.

\section{Results}

The measurements of the chromosomes of the I5 male cells are presented in Table I. Based on the arm ratio, $r=\frac{q}{p}$, and according to the karyotype system by LEVAN et al. (I964), the pig karyotype consists of 6 pairs of metacentric, 4 pairs of submetacentric, 2 pairs of subtelocentric, and 6 pairs of acro-/telo-centric autosomes. The $\mathrm{X}$ and the $\mathrm{Y}$ chromosomes are both metacentric.

The relative length of the $\mathrm{X}$ chromosome is $5 \mathrm{p}$. Ioo of the total haploid female chromoscme length, which means, that the $\mathrm{X}$ chromosome is the third longest metacentric chromosome. The $\mathrm{Y}$ is the smallest chromosome of all. The only autosome which according to the banding pattern is sometimes difficult to distinguish from the $\mathrm{X}$ chromosome is No. 8 . From Table $\mathrm{I}$ it is seen that the arm ratio for the $\mathrm{X}$ chromosome is I.42, and for pair No. 8 is I.I8. This means that pair No. 8 is more metacentric than the $\mathrm{X}$ chromosome.

In Table I the numbering of chromosomes in Column $A$ agrees with the Reading system presented at the 3. European Symposium in Paris 1977 by HANSEN (I 977). The idiogram of the pig according to this numbering is presented in Fig. I. Column $B$ in Table I shows the preliminary numbering of the chromosomes from the Reading Conference (I976), without changing the position of the metacentric chromosome No. 5 (in that system) from the submetacentric group to the metacentric group. The arrangement of the chromosomes is shown in the idiogram in Fig. 2. Column $C$ represents the numbering of chromosomes 


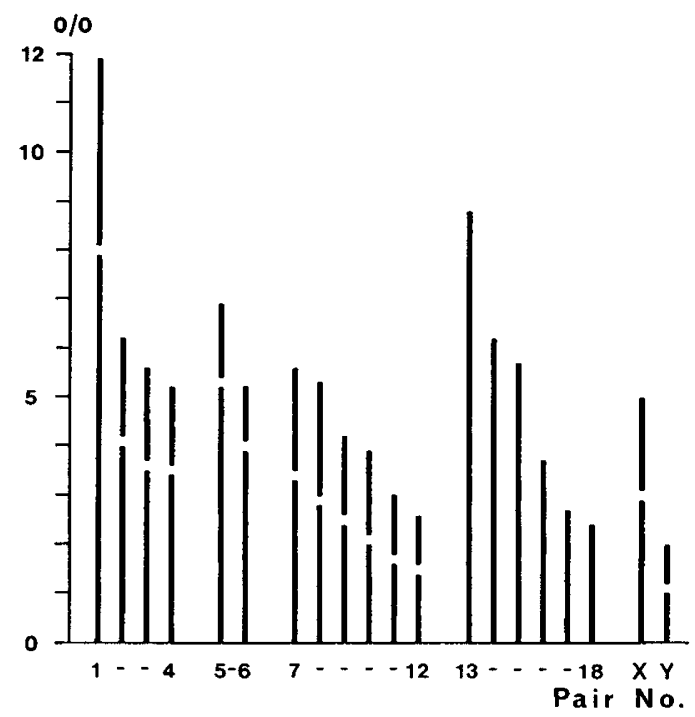

FIG. I. - Idiogram of domestic pig according to the Reading system (Paris, I977), based on the measurements in Table $I$.

Idiogramme du porc domestique selon le Système de Reading (Paris, 1977), basé sur les mensurations de la table $I$.

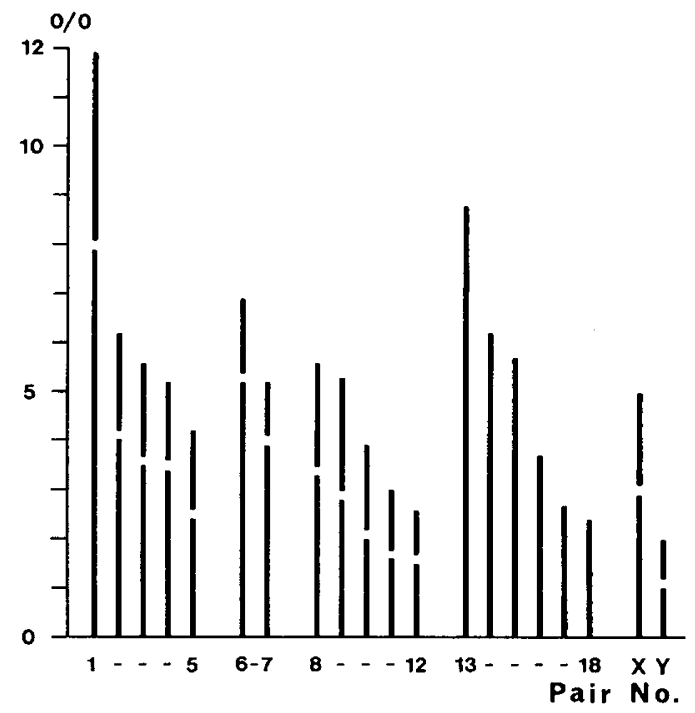

FIG. 2. - Idiogram of domestic pig according to the preliminary system of the Reading Conference (I976).

Idiogramme du porc domestique selon le système préliminaire à la Reading Conference (I976). 


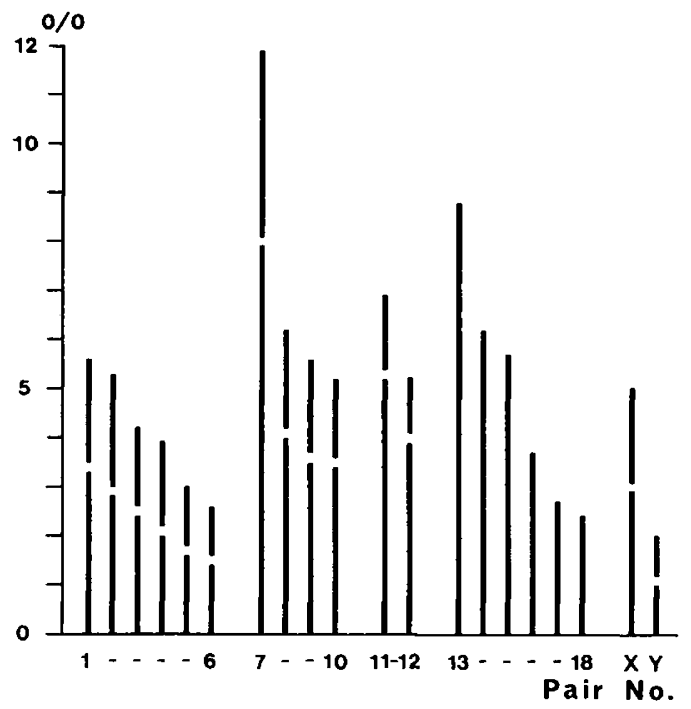

FIG. 3. - Idiogram of domestic pig according to the system by LEVAN et al. (rg64).

Idiogramme du porc domestique selon le système de LEVAN et al. ( 1964$)$.

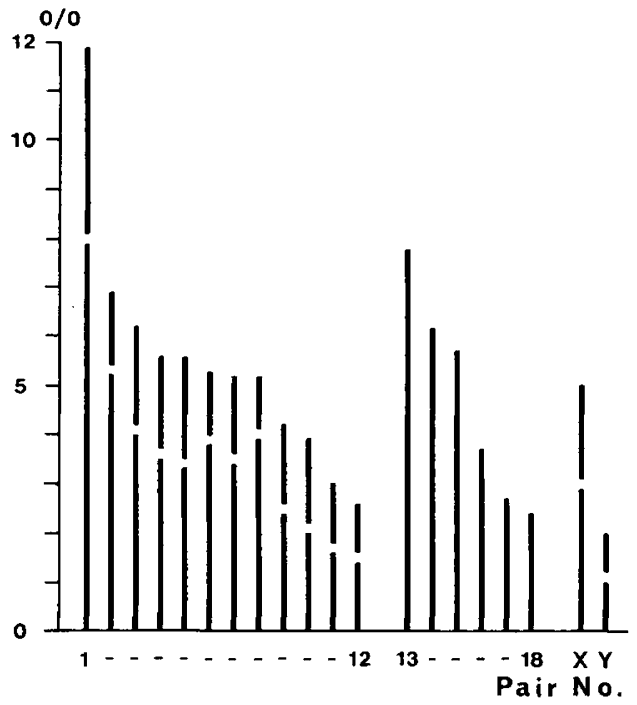

Frg. 4. - Idiogram of domestic pig according to the bi-and one-armed system. Idiogramme du porc domestique selon le système bi-et mono-bras. 
TABLE I

Revised study of the relative length and the arm ratio of the mitotic chromosomes of the domestic pig (Sus scrofa domestica) Maan of 15 male cells

Etude revue de la longueur relative et du rapport des bras des chromosomes mitotiques du porc domestique (Sus scrofa domestica)

\begin{tabular}{|c|c|c|c|c|c|c|c|c|}
\hline \multicolumn{4}{|c|}{ Pair No. } & \multicolumn{3}{|c|}{ Relative length $\left(^{(1)}\right.$} & \multirow{2}{*}{$r=\frac{q}{p}$} & \multirow{2}{*}{$\operatorname{Term}\left(^{2}\right.$} \\
\hline A & $\mathrm{B}$ & C & $\mathrm{D}$ & $\begin{array}{c}\text { Short } \\
\operatorname{arm}(p)\end{array}$ & $\begin{array}{l}\text { Long } \\
\operatorname{arm}(q)\end{array}$ & $(p+q)$ & & \\
\hline I & I & 7 & I & $3.9 \mathrm{I}$ & 8.04 & I I .95 & 2.06 & $\mathrm{sm}$ \\
\hline 2 & 2 & 8 & 3 & $2.1 \mathrm{I}$ & 4.07 & 6.18 & I.93 & $\mathrm{sm}$ \\
\hline 3 & 3 & 9 & 4 & I. 98 & 3.62 & 5.60 & $\mathrm{r} .83$ & $\mathrm{sm}$ \\
\hline 4 & 4 & IO & 7 & I. 78 & 3.46 & 5.24 & I. 94 & $\mathrm{sm}$ \\
\hline 5 & 6 & II & 2 & I. 60 & 5.26 & 6.86 & 3.29 & st \\
\hline 6 & 7 & I 2 & 8 & I.I 8 & 3.99 & 5.17 & $3 \cdot 3^{8}$ & st \\
\hline 7 & 8 & $\mathbf{I}$ & 5 & 2.22 & $3 \cdot 38$ & 5.60 & I. 52 & $\mathrm{~m}$ \\
\hline 8 & 9 & 2 & 6 & 2.43 & 2.86 & 5.29 & I. 18 & $\mathrm{~m}$ \\
\hline 9 & 5 & 3 & 9 & 1.70 & 2.46 & 4.16 & I. 45 & $\mathrm{~m}$ \\
\hline IO & Io & 4 & Io & 1.80 & 2. I I & $3.9 \mathrm{I}$ & I. 17 & $\mathrm{~m}$ \\
\hline II & I I & 5 & I I & r. 37 & I. 66 & 3.03 & $\mathrm{I} .2 \mathrm{I}$ & $\mathrm{m}$ \\
\hline I 2 & I 2 & 6 & I 2 & I.I 7 & I. 45 & 2.62 & I. 24 & $\mathrm{~m}$ \\
\hline I3 & I3 & I 3 & I 3 & - & - & 8,76 & - & $\mathrm{t}$ \\
\hline I4 & I4 & 14 & I 4 & - & - & 6.19 & - & $t$ \\
\hline I 5 & I 5 & I 5 & I 5 & - & - & 5.73 & - & $\mathrm{t}$ \\
\hline 16 & 16 & I 6 & I 6 & - & - & 3.65 & - & $t$ \\
\hline I 7 & I7 & I 7 & I 7 & - & - & 2.67 & - & $t$ \\
\hline I 8 & 18 & 18 & & - & - & 2.35 & - & $t$ \\
\hline I9 & 19 & I9 & I9 $\mathrm{X}$ & 2.08 & 2.95 & 5.03 & I. 42 & $\mathrm{~m}$ \\
\hline & & & & 0.86 & I.09 & I.95 & I. 27 & $\mathrm{~m}$ \\
\hline
\end{tabular}

A : Reading system, Paris, I977.

B : Preliminary Reading system.

C : Levan system.

(I) Per cent of the total haploid female chromosome length.

(2) According to IrEvaN et al. (Ig64).

according to the system by LEVAN et al. (I964), the subgroups $\mathrm{m}$, sm, st, and $\mathrm{t}$. The corresponding idiogram is shown in Fig. 3. Column $D$ represents the numbering according to the bi- and one-armed system, and Fig. 4 the corresponding idiogram.

\section{Discussion and conclusion}

By the different banding methods it is now possible to identify all the pig chromosomes. As a consequence of these results, some authors think it is unnecessary today to characterize the chromosomes by the relative length, even by description of chromosomes in connection with standardization of karyotypes of very important domestic animals, see e.g. the Reading Conference (r976). As an argument it is stated that the banding methods identify the chromosomes in a sufficiently high degree of certainty. 
For many reasons it is necessary to know the relative length of each pair of the chromosomes, e.g. $a$ : classification of chromosomes according to the system by LEVAN et al. (I964), $b$ : exact placing of bands on $p$ and $q, c$ : identification and description of deletions, duplications, and translocations, and $d$ : gene mapping by exact placing of gene loci (in bands) on $p$ and $q$ in relation to the position of other genes (and bands).

Sequential Q-band/Giemsa staining of the chromosomes seems to be the only method for measuring preidentified chromosomes, HANSEN (I975 $b$ ), because the chromatids are not disturbed or perhaps changed by incorporation of chemicals. Maybe this is the reason why only two authors have described the relative length of the pig chromosomes. The present measurements of the relative length of the pig chromosomes, Table I, agree very well with the results by HANSEN (I976a, I977) and LIN et al. (I980). It appears that the $\mathrm{X}$ chromosome and chromosome No. 8 are of nearly equal length, but No. $8(r=\mathrm{I} . \mathrm{I} 8)$ is more metacentric than the $\mathrm{X}$ chromosome $(r=\mathrm{I} .42)$. The relative length of the $\mathrm{X}$ chromosome constitutes $5 \mathrm{p}$. Ioo of the total female haploid chromosome complement, which agrees with the relative length of the $\mathrm{X}$ chromosome of other animals like cattle, goat, sheep, zebra, and horse as described by HANSEN (I972a, I973a, I973 $b$, $\mathrm{I} 975 a$, I976b), and with the length of the human $\mathrm{X}$ chromosome, Paris Conference (I97I).

From a systematic point of view it is valuable to know the relative length of each pair of the chromosomes. When an arrangement of chromosomes in karyotype is recommended, it must be a demand. In the first descriptions of the banding patterns of the pig chromosomes by GusTavsson et al. (I972), HANSEN (I972), BerGer (I972), EChard (I973), Sysa (I973), and HANSEN-Merander et al. (I974) no measurements were presented. At the Reading Conference (1976) it was decided to use the karyotype system by LEVAN et al. (I964), which needs measurements for characterization of the chromosomes, Table I, Column $\mathrm{C}$ and Fig. 3. However, as a preliminary system the karyotype presented by GusTAVSSON et al. (I972), which does not agree with the system by LEVAN et al. (I964), was chosen. Unfortunately, measurements on Io Q-band/Giemsa stained cells presented at the conference by HANSEN (I976a) were not taken into consideration.

Chromosome No. 5 in the preliminary Reading karyotype system, Table I, Column B, was placed in the submetacentric group, even if it is metacentric, because it was only identified by the $Q$-band patterns, and for that reason missed the heavily stained distal R-band on $p$, HANSEN (1976a, I977). At the Reading Conference (I976) it was decided to put No. 5 to the metacentric group if further results confirm those of HANSEN (I976a, I977). Recently the results have been confirmed by LIN et al. (I980). The system with the correct position of pair No. 5 is described by Hansen (I977) and shown in Table I, Column A and Fig. I.

The order of the different subgroups in the Reading pig karyotype (sm, st, $\mathrm{m}$, and $\mathrm{t}$ ) disagree with that of the system by LEVAN et al. (I964), which is $\mathrm{m}$, sm, st, and $t$. Of course it is possible to standardize any type of chromosome arrangement as a standard karyotype, but at the Reading Conference (I976) it was decided to use the system by LEVAN et al. (I964).

Before and after the introduction of the banding methods, different karyotype systems for the chromosomes of the domestic pig have been used. From a systematic point of view it seems now that only two possibilities exist for a standard karyotype system for the chromosomes of domestic animals, and especially for the domestic pig: I: the bi- and one-armed system, Table I, Column D, and Fig. 4, or 2: the exact system by LEVAN et al. (r964), Table I, Column C, 
and Fig. 3. Most of the zoologists, veterinarians, and cytogeneticists until now have used the bi- and one-armed system. This system is very easy for practical use, for description of cytogenetic evolution, for publishing of whole karyotypes, and for demonstration of chromosome aberrations. For these reasons the biand one-armed karyotype system is recommended for domestic animals, but in connection with the mathematical system by LEVAN et al. (1964) as demonstrated in Table I, Column D, and in Fig. 4. An approximate combination of these two systems has been used by HANSEN-MELANDER et al. (I974). Furthermore, it is recommended to put 6 pairs of chromosomes into each row, and to keep the sex chromosomes apart from the autosomes.

Receveid for publication in January 1981 .

\section{Acknowledgements}

The author wisches to thank laboratory technicians Mrs. Else HANSEN and Bente KJAERSGAARD for skillful assistance. The work was supported by the Danish Agricultural and Veterinary Research Council, Grant No. 5I3-1551/72 and No. 513-2534/73.

\section{Résumé}

\section{La longueur relative des chromosomes du porc avec une proposition de système caryotypique}

L'étude de la longueur relative de $p$ et $q$ des différentes paires chromosomiques du porc domestique (Sus scrofa domestica) a été reprise à partir de 55 cellules. La longueur relative du chromosome $\mathrm{X}$ est de $5 \mathrm{p}$. I oo du complément chromosomique haploïde femelle. Différents systèmes caryotypiques, y compris le système de la Reading Conference, sont discutés. On recommande une combinaison du système bi- et mono-bras avec le système de LEVAN et al. (1964) comme système caryotypique international pour les chromosomes du porc.

\section{References}

BERGER R., 1972. Étude du caryotype du porc avec une nouvelle technique. Exptl. Cell Res., 75, 298-300.

EChARD Geneviève, 1973. Étude des bandes chromosomiques du porc et de trois différentes souches de rein de porc en culture (PK 15, F et RP). Ann. Génet. Sél. Anim., 5, I-2I.

Gustavsson I., HAGeltorn M., Johansson C., ZECH L., 1972. Identification of the pig chromosomes by the quinacrine mustard fluorescence technique. Exptl. Cell Res., 70, 47I-474.

HANSEN K. M., I $972 a$. Bovine chromosomes identified by quinacrine mustard and fluorescence microscopy. Hereditas, 70, 225-234.

HANSEN K. M., I972b. The karyotype of the pig (Sus scrofa domestica), identified by quinacrine mustard staining and fluorescence microscopy. Cytogenetics, 11, 286-294.

HANSEN K. M., I973a. Q-band karyotype of the goat (Capra hircus) and the relation between goat and bovine Q-bands. Hereditas, 75, I I9-I 30.

HANSEN K. M., I $973 b$. The karyotype of the domestic sheep (Ovis aries) identified by quinacrine mustard staining and fluorescence microscopy. Heveditas, 75, 233-240.

HANSEN K. M., 1975a. The G- and Q-band karyotype of Böhm's or Grant's zebra (Equus burchelli böhmi). Hereditas, 81, I33-140. 
HANSEN K. M., 1975b. Animal chromosomes and banding methods. Proceeding of: 2. Europäisches Kolloquium über Zytogenetik (Chromosomenpathologie) in Veterinärmedizin, Tierzucht und Säugetierkunde. Giessen, 29. und 30. September 1975, 33-43.

HANSEN K. M., I $976 a$. The karyotype of the pig. Contribution to the Reading Karyotype Conference, 2nd-6th August 1976. Unpublished results.

HANSEN K. M., 1976b. The karyotype of the horse. Contribution to the Reading Karyotype Conference, 2nd-6th August i976. Unpublished results.

HANSEN K. M., 1977. Identification of the chromosomes of the domestic pig (Sus scrofa domestica). An identification key and a landmark system. Ann. Génét. Sél. Anim., 9, 517-526.

HANSEN K. M., I980. G-band identification of the X chromosome of the domestic pig (Sus scrofa domestica). Proceeding of the $4^{\text {th }}$ European Colloquium on Cytogenetics of Domestic Animals. Uppsala, June ro-r3. In press.

HANSEN-Melander E., Melander Y., I974. The karyotype of the pig. Hereditas, 77, I49-158.

Levan A., Freidga K., Sandberg A. A., I964. Nomenclature for centromeric position on chromosomes. Hereditas, 52, $20 \mathrm{r}-220$.

Lin C. C., Brederman B. M., Jamro H. K., Hawthorne A. B., Church R. B., i98o. Porcine (Sus scrofa domestica) chromosome identification and suggested nomenclature. Canad. J. Genet. Cytol., 22, го3-г16.

PARIS CONFERENCE (I97I). Standardization in Human Cytogenetics. Birth Defects: Original Article Series, VIII, 7, 1972. The National Foundation, New York.

READING CONFERENCE (I976). Standardization of banded karyotypes of domestic animals. Edited by C. E. Ford, D. L. Pollock, and I. Gustavsson. Heveditas, 92, I45-I62.

Sysa P., I973. Fluorescence characteristics of the karyotype of the pig. In vitro, 2/2A, 56-67. 